\title{
PERBANDINGAN KADAR HEMOGLOBIN PRA DAN PASCA HEMODIALISA PADA PASIEN PENDERITA GAGAL GINJAL KRONIK DI RSUD KARAWANG
}

\author{
*Atna Permana ${ }^{1)}$, Any Rahayu ${ }^{1)}$ \\ ${ }^{1}$ Program Studi D III Analis Kesehatan,Fakultas Kesehatan,Universitas Mohammad Husni Thamrin \\ Correspondence author: Atna Permana, atnap@yahoo.com, Jakarta, Indonesia
}

\begin{abstract}
ABSTRAK
Gagal Ginjal adalah hilangnya fungsi ginjal, dan dibagi menjadi dua kategori yaitu gagal ginjal akut dan gagal ginjal kronik. Gagal Ginjal Kronik adalah suatu keadaan klinis yang ditandai dengan penurunan fungsi ginjal yang irreversible, pada suatu derajat yang memerlukan terapi pengganti ginjal yang tetap, berupa dialisis atau transplantasi ginjal. Penyakit Gagal Ginjal Kronik (GGK) prevalensinya semakin meningkat setiap tahunnya di negara-negara berkembang termasuk Indonesia yang diperkirakan ada sekitar 40-60 kasus per juta penduduk per tahun. Hemodialisa merupakan salah satu terapi yang rutin dilakukan pada pasien Gagal Ginjal Kronik. Penelitian ini bertujuan untuk mengetahui kadar hemoglobin pada penderita gagal ginjal kronik pra dan pasca hemodialisa.

Penelitian ini dilakukan terhadap 50 pasien penderita gagal ginjal kronik di RSUD Karawang periode Maret-Juni 2018. Data diperoleh dari bagian Rekam medik RSUD Karawang. Data diambil dan dicatat dari formulir rekam medis mengenai kadar Hb pada pasien Gagal Ginjal Kronik pra dan pasca hemodialisa. Data diuji statistik dengan uji Paired Sample T-Test.

Dari hasil penelitian ini diperoleh nilai rata-rata kadar hemoglobin pra hemodialisa adalah $8.4 \mathrm{~g} / \mathrm{dl}$, dengan kadar terendah $7.0 \mathrm{~g} / \mathrm{dl}$ dan kadar tertinggi $10.3 \mathrm{~g} / \mathrm{dl}$. Sedangkan nilai rata-rata kadar hemoglobin pasca hemodialisa adalah $9.0 \mathrm{~g} / \mathrm{dl}$, dengan kadar terendah $7.3 \mathrm{~g} / \mathrm{dl}$ dan kadar tertinggi $10.6 \mathrm{~g} / \mathrm{dl}$. Terdapat perbedaan yang signifikan antara kadar hemoglobin pra hemodialisa dengan kadar hemoglobin pasca hemodialisa.
\end{abstract}

Kata Kunci : Gagal Ginjal Kronik, Hemodialisa, Hemoglobin

ABSTRACT

Renal failure is a loss of renal function, and is divided into two categories namely acute renal failure and chronic renal failure. Chronic Renal Failure is a clinical condition characterized by a decrease in irreversible renal function, to a degree that requires permanent kidney replacement therapy, in the form of dialysis or kidney transplantation. Chronic Kidney Failure Disease (GGK) prevalence is increasing every year in developing countries including Indonesia which is estimated to have about 40-60 cases per million inhabitants per year. Hemodialysis is one of the routine therapies performed in chronic renal failure patients. This study aims to find out hemoglobin levels in people with pre and post-hemodialysis chronic renal failure.

The study was conducted on 50 patients with chronic renal failure at Karawang Hospital from March to June 2018. The data was obtained from the medical records section of Karawang Hospital. Data is taken and recorded from medical records form regarding $\mathrm{Hb}$ levels in pre and post-hemodialysis Chronic Renal Failure patients. Data tested statistically with Paired Sample T-Test test.

From the results of this study obtained the average value of pre-hemomodialisa hemoglobin levels is $8.4 \mathrm{~g} / \mathrm{dl}$, with the lowest level of $7.0 \mathrm{~g} / \mathrm{dl}$ and the highest level of $10.3 \mathrm{~g} / \mathrm{dl}$. While the average value of posthemomodialisa hemoglobin levels is $9.0 \mathrm{~g} / \mathrm{dl}$, with the lowest rate of $7.3 \mathrm{~g} / \mathrm{dl}$ and the highest level of $10.6 \mathrm{~g} / \mathrm{dl}$. There is a significant difference between pre-hemomodialisa hemoglobin levels and post-hemomodialisa hemoglobin levels.

Keywords : Chronic Kidney Failure, Hemodialysis, Hemoglobin

Open Journal System (OJS): journal.thamrin.ac.id

http://journal.thamrin.ac.id/index.php/anakes/issue/view/33 


\section{PENDAHULUAN}

Di Negara maju, penyakit kronik tak menular (chronic non-communicable diseases) terutama penyakit kardiovaskuler, diabetes mellitus, dan penyakit ginjal kronik, sudah menggantikan penyakit menular (communicable diseases) sebagai masalah kesehatan masyarakat utama. (Susalit Endang, 2006).

Penyakit Gagal Ginjal Kronik (GGK) prevalensinya semakin meningkat setiap tahunnya di negaranegara berkembang termasuk Indonesia yang diperkirakan ada sekitar 40-60 kasus per juta penduduk per tahun. Sementara itu di Amerika dari 142.488 pasien terdapat 90\% nya menjalani hemodialisis. (Siviani, dkk, 2011) bahkan terdapat 200.000 dialisis dan transplatasi ginjal pada pasien dengan peningkatan hampir 10\% setiap tahunnya. (Lardo dan Nasution, 2004).

Hemodialisa merupakan salah satu terapi yang rutin dilakukan pada pasien GGK. Hemodialisa dapat menggantikan fungsi ginjal untuk mempertahankan cairan, elektrolit dan membuang sisa-sisa metabolisme dari tubuh sehingga dapat memperpanjang umur pasien dan meningkatkan kualitas hidup pasien. (National Kidney Foundation, 2015).

Tindakan hemodialisa pada pasien GGK dengan kadar ureum dan kreatinin yang tinggi merupakan cara untuk mempertahankan kelangsungan hidup pasien dengan tujuan menurunkan kadar ureum, kreatinin, dan zat toksik lainnya dalam darah. (Nugraha-ni, 2007)

Pada penyakit GGK terjadi penurunan fungsi ginjal secara perlahan dan irreversible sehingga terjadi gagal ginjal yang memerlukan terapi pengganti yang membutuhkan biaya mahal. Penyakit GGK biasanya disertai beberapa komplikasi seperti penyakit kardiovaskular, penyakit saluran napas, penyakit saluran cerna, kelainan di tulang dan otot, serta anemia. (Susalit, E., 2006).

Penderita gagal ginjal kronik yang menjalani terapi hemodialisa juga dapat mengalami anemia, anemia muncul ketika kreatinin turun kira-kira $40 \mathrm{ml} /$ menit, anemia akan menjadi lebih berat apabila fungsi ginjal memburuk.

Anemia sering terjadi pada pasien GGK dengan prevalensi dan keparahan meningkat sesuai dengan peningkatan keparahan penyakit. Beberapa penyebab anemia pada GGK antara lain penurunan produksi eritropoetin, defisiensi besi, pemendekan umur sel darah merah, anemia akibat toksik uremia, inflamasi atau pendarahan. Penelitian menunjukkan bahwa dengan mengobati anemia dapat meningkatkan kualitas hidup pasien, mengurangi angka kematian dan kesakitan, serta memperbaiki prognosis pada pasien GGK. (Mechanisms of Anemia in Chronic Kidney Disease, 2012).

Eritropoetin pada GGK menurun akibat efek toksin pada sumsum tulang yang tertahan dan maupun akibat biosintesis eritropoetin yang berkurang dari ginjal yang sakit atau karena adanya inhibitor eritropoetin. Pemberian eritropoetin manusia rekombinan (EPO) menyebabkan peningkatan hematokrit dan hemoglobin, memberikan kesan bahwa eritropoetin serum yang berkurang mungkin merupakan faktor yang lebih penting. (Brenner BM dan Mackenzie HS, 1999).

Open Journal System (OJS): journal.thamrin.ac.id 
Hemodialisa merupakan pengaturan yang efektif bagi keadaan gagal ginjal, tetapi sekresi eritropoetin tidak mengalami perbaikan dan anemia tetap berlanjut. Pada pasien dengan terapi hemodialisa mengalami penurunan kadar asam folat di dalam dialisis fluid. Dalam buku Clinical Nephorology masalah yang paling berpengaruh pada pasien dengan terapi dialisis adalah anemia yang menetap, dengan kadar hemoglobin berkisar antara 4-15 g/dl dan rata-rata $8 \mathrm{~g} / \mathrm{dl}$. Pada umumnya anemia pada penderita GGK disebabkan oleh berkurangnya hemoglobin dalam darah akibat pengambilan darah untuk pemeriksaan laboratorium atau pada saat melakukan hemodialisa. Selain itu, asupan makan pasien yang kurang juga dapat menyebabkan anemia menjadi semakin buruk.

Penelitian sebelumnya dilakukan oleh Ulya I di RS PKU Muhammadiyah Yogyakarta pada tahun 2007 terhadap 40 pasien penderita GGK dengan hasil kadar hemoglobin 3-10.8 g/dl dengan rata-rata 7 $\mathrm{g} / \mathrm{dl}$ untuk pra hemodialisa dan hasil kadar hemoglobin 5-12.8 g/dl dengan rata-rata $9.25 \mathrm{~g} / \mathrm{dl}$ untuk pasca hemodialisa. Penelitian serupa juga pernah dilakukan oleh Hilda Riani di RS Haji Jakarta pada tahun 2015 dengan hasil rata-rata kadar hemoglobin $8.5 \mathrm{~g} / \mathrm{dl}$. Sehingga dilakukan penelitian kembali di RSUD Karawang untuk melihat nilai kadar hemoglobin pra dan pasca hemodialisa pada penderita Gagal Ginjal Kronik.

Berdasarkan latar belakang diatas, Penulis membatasi pemeriksaan kadar hemoglobin pada penderita gagal ginjal kronik pra hemodialisa dan pasca hemodialisa.

\section{METODOLOGI PENELITIAN}

Penelitian dilakukan pada bulan Juli-Agustus 2018 di Rekam Medis RSUD Karawang. Populasi adalah pasien yang di diagnosa menderita gagal ginjal kronik berdasarkan data rekam medis di RSUD Karawang. Data hasil pemeriksaan hemoglobin pra hemodialisa dan pasca hemodialisa pada pasien yang didiagnosa gagal ginjal kronik di Laboratorium RSUD Karawang periode Maret-Juni 2018.

Penelitian ini dilakukan dengan mengumpulkan data-data sekunder dari RSUD Karawang dengan tahap sebagai berikut : Meminta surat izin dari kampus untuk meminta data ke RSUD Karawang. Mengajukan surat izin yang ditujukan ke direktur RSUD Karawang. Melihat data rekam medis pada pasien yang menderita gagal ginjal kronik. Mencatat kadar hemoglobin sebelum dan sesudah hemodialisa pada penderita GGK. Setelah didapatkan data, selanjutnya dilakukan pengolahan data.

Data dalam penelitian ini adalah data dari pemeriksaankadar Hemoglobin pra dan pasca hemodialisa pada pasien gagal ginjal kronik.

Data yang diperoleh akan dianalisa menggunakan uji normalitas Shapiro-Wilk dan dilanjutkan dengan uji statistikPaired Sample T-Test pada dua sampel berpasangan. Kemudian hasil disimpulkan dan disajikan secara deskriptif.

Open Journal System (OJS): journal.thamrin.ac.id 


\section{HASIL DAN PEMBAHASAN}

\section{Hasil}

Berdasarkan data hasil pemeriksaan kadar hemoglobin pra dan pasca hemodialisa pada penderita Gagal Ginjal Kronik di RSUD Karawang tahun 2018 pada 50 sampel diperoleh hasil sebagai berikut

\section{Tabel 5.}

Hasil Nilai Min, Max, dan Rata-Rata Kadar Hb Pra dan Pasca Hemodialisa.

\begin{tabular}{ccccc}
\hline Variasi Sampel & N & $\begin{array}{c}\text { Kadar } \\
\text { Minimum }\end{array}$ & $\begin{array}{c}\text { Kadar } \\
\text { Maximum }\end{array}$ & Rata-Rata \\
\hline Pra Hemodialisa & 50 & 7.0 & 10.3 & 8.444 \\
\hline Pasca Hemodialisa & 50 & 7.3 & 10.6 & 9.008 \\
\hline
\end{tabular}

Berdasarkan tabel 5. Didapatkan nilai rata-rata kadar hemoglobin pra hemodialisa pada 50 sampel adalah $8.444 \mathrm{~g} / \mathrm{dl}$, dengan kadar terendah adalah $7.0 \mathrm{~g} / \mathrm{dl}$ dan kadar tertinggi adalah $10.3 \mathrm{~g} / \mathrm{dl}$. Sedangkan nilai rata-rata kadar hemoglobin pasca hemodialisa pada 50 sampel adalah $9.008 \mathrm{~g} / \mathrm{dl}$, dengan kadar terendah adalah $7.3 \mathrm{~g} / \mathrm{dl}$ dan kadar tertinggi adalah $10.6 \mathrm{~g} / \mathrm{dl}$.

Tabel 6.

Hasil Uji Paired Sampel T-Test.

\begin{tabular}{cccc}
\hline Mean & SD & T & Sig. \\
\hline-.5640 & .4346 & -9.176 & .000 \\
\hline
\end{tabular}

Berdasarkan tabel 6. Diperoleh hasil Uji Paired Sampel T-Test dengan nilai signifikan (p) pada pra dan pasca hemodialisa adalah 0.000 , rata-rata selisih hasil kadar hemoglobin pra dan pasca hemodialisa adalah -0.5640 dengan standar deviasi 0.4346 dan nilai $t$ statistik adalah -9.176 . Dengan hasil nilai $\mathrm{p}=0.000(\mathrm{p}<0.05)$, sehingga dapat disimpulkan terdapat perbedaan hasil yang signifikan antara kadar hemoglobin pra dan pasca hemodialisa.

\section{Pembahasan}

Gagal Ginjal Kronik adalah suatu keadaan klinis yang ditandai dengan penurunan fungsi ginjal yang irreversible, pada suatu derajat yang memerlukan terapi pengganti ginjal yang tetap, berupa dialisis atau transplantasi ginjal. (Suwitra, K., 2006).

Dari data hasil pemeriksaan hemoglobin pra dan pasca hemodialisa pada tabel 5, diperoleh hasil 7.0$10.3 \mathrm{~g} / \mathrm{dl}$ dengan rata-rata $8.444 \mathrm{~g} / \mathrm{dl}$ untuk kadar hemoglobin pra hemodialisa dan 7.3-10.6 g/dl dengan rata-rata $9.008 \mathrm{~g} / \mathrm{dl}$ untuk kadar hemoglobin pasca hemodialisa. Sebelumnya pernah dilakukan Open Journal System (OJS): journal.thamrin.ac.id 
penelitian oleh Ulya I di RS PKU Muhammadiyah Yogyakarta pada tahun 2007 terhadap 40 pasien penderita GGK dengan hasil kadar $\mathrm{Hb} 3-10.8 \mathrm{~g} / \mathrm{dl}$ dengan rata-rata $7 \mathrm{~g} / \mathrm{dl}$ untuk pra hemodialisis dan hasil kadar $\mathrm{Hb}$ 5-12.8 g/dl dengan rata-rata $9.25 \mathrm{~g} / \mathrm{dl}$ untuk pasca hemodialisa. Berdasarkan hasil penelitian diatas, terdapat perbedaan hasil antara penelitian yang dilakukan oleh peneliti dengan hasil penelitian sebelumnya oleh Ulya I pada tahun 2007. hal tersebut dikarenakan data yang digunakan oleh peneliti sebelumnya adalah data hasil pemeriksaan $\mathrm{Hb}$ pra dan pasca hemodialisa dengan periode 1 tahun terhadap 40 pasien, sedangkan data yang digunakan peneliti adalah seluruh data hasil pemeriksaan $\mathrm{Hb}$ pra dan pasca hemodialisa dengan periode 4 bulan Maret-Juni yang berjumlah 50 pasien.

Berdasarkan hasil rata-rata $\mathrm{Hb}$ (tabel 5), peneliti berasumsi didapatkan peningkatan kadar hemoglobin hemodialisa akan tetapi kadarnya tetap rendah atau dibawah nilai normal. Dijelaskan dalam buku Clinical Nephorology masalah yang paling berpengaruh pada pasien dengan terapi dialisis adalah anemia yang menetap, dengan kadar hemoglobin berkisar antara 4-15 g/dl dan rata-rata $8 \mathrm{~g} / \mathrm{dl}$.

Anemia sering terjadi pada pasien GGK dengan prevalensi dan keparahan meningkat sesuai dengan peningkatan keparahan penyakit. Beberapa penyebab anemia pada GGK antara lain penurunan produksi eritropoetin, defisiensi besi, pemendekan umur sel darah merah, anemia akibat toksik uremia, inflamasi atau pendarahan. Selain itu, asupan makan pasien yang kurang juga dapat menyebabkan anemia menjadi semakin buruk.

Rata-rata jumlah eritrosit, kadar hemoglobin dan kadar hematokrit menunjukkan peningkatan yang signifikan secara statistik pada pasien gagal ginjal pasca hemodialisis jika dibandingkan dengan kadar sebelum hemodialisis. Peningkatan jumlah eritrosit, kadar hemoglobin dan kadar hematokrit sesudah hemodialisis dijelaskan bahwa sebelum hemodialisis, pasien biasanya mengalami hipervolemia, dimana pada pasien gagal ginjal mengalami penurunan fungsi ekskresi cairan dan sodium. Peningkatan jumlah cairan ini akan menyebabkan dilusi sehingga jumlah eritrosit, kadar hemoglobin dan kadar hematokrit menjadi lebih rendah. (Alghythan AK, 2012)

Menurut Steffanson (2011), pada penderita GGK yang menjalani dialisis ditemukan perbaikan eritropoesis yang signifikan. Hal ini dikarenakan pembuangan toksik uremik "suppressor eritroid" saat proses dialysis. Penelitian Richardson, dkk (2007) juga menunjukkan terjadinya peningkatan hemoglobin yang signifikan dalam 6 bulan pertama setelah memulai hemodialisis.

Penelitian yang dilakukan Ayesh, dkk (2014) menunjukkan bahwa rata-rata hemoglobin meningkat signifikan pada pasien dengan hemodialisis yang adekuat dibandingkan dengan pasien hemodialisis yang tidak adekuat. Rata-rata kadar Eritropoetin Stimulating Agent (ESA) lebih rendah pada pasien dengan hemodialisis yang adekuat dibandingkan dengan pasien hemodialisis yang tidak adekua.

Open Journal System (OJS): journal.thamrin.ac.id 


\section{SIMPULAN}

Setelah dilakukan analisa terhadap 50 pasien penderita GGK yang melakukan pemeriksaan kadar hemoglobin pra dan pasca hemodialisa di RSUD Karawang periode Maret-Juni 2018, maka diperoleh kesimpulan sebagai berikut : Kadar hemoglobin pra hemodialisa pada penderita GGK diperoleh hasil terendah $7.0 \mathrm{~g} / \mathrm{dl}$ dan hasil tertinggi $10.3 \mathrm{~g} / \mathrm{dl}$ dengan rata-rata $8.4 \mathrm{~g} / \mathrm{dl}$. Kadar hemoglobin pasca hemodialisa pada penderita GGK diperoleh hasil terendah $7.3 \mathrm{~g} / \mathrm{dl}$ dan hasil tertinggi $10.6 \mathrm{~g} / \mathrm{dl}$ dengan rata-rata $9.0 \mathrm{~g} / \mathrm{dl}$. Didapatkan perbedaan hasil pemeriksaan kadar hemoglobin pra hemodialisa dengan kadar hemoglobin pasca hemodialisa pada penderita GGK di RSUD Karawang.

\section{UCAPAN TERIMA KASIH}

Penulis mengucapkan terima kasih kepada RSUD Karawang, dan Prodi D III Analis Kesehatan Fakultas Kesehatan Universitas MH Thamrin. dalam penelitian ini.

\section{DAFTAR PUSTAKA}

1. Ayesh (Haj Yousef), M.H., Bataineh, A., Elamin, E. et al. BMC Nephrol. 15: 155. doi:10.1186/1471-2369-15-155. 2014.

2. Babitt, J. L. dan Lin, H. Y. Mechanism of Anemia in CKD. J Am Soc Nephrol. 23:1-4. 2012.

3. Cohen, D. and Valeri, A. M. Treatment of irreversible renal failure. Dalam: Crow, M., Doroshow, J., Drazen, J., Griggs, R., Landry, D., Levinson, W., et al., penyunting. Goldman's Cecil Medicine 25th ed. Philadelphia: Elsevier Saunders. hlm. 841-7. 2012.

4. Guyton, A. C. dan Hall, J. E. Guyton and Hall Textbook of Medical Physiology 13th ed. Philadelphia: Saunders Elsevier. 2015.

5. Markum, H. M. S. Gagal Ginjal Akut. Dalam Setiati, S., Alwi, I., Sudoyo, A. W., Simadibrata, M., dan Setiyohadi, B., penyunting. Buku Ajar Ilmu Penyakit Dalam. Edisi ke-2. Jakarta: Interna Publishing.Hl 574. 2006.

6. Pearce, Evelyn C. Anatomi dan Fisiologi untuk Paramedis. Jakarta: PT. Gramedia. 2015.

7. Price, S. A. Patofisiologis : Konsep Klinis proses-proses penyakit. 2006.

8. Susalit E,Suhardjono, Rahardjo P. Dialisis dalam Buku Ajar Ilmu Penyakit Dalam (Jilid II). Balai Penerbit FKUI.Jakarta. 2006.

9. Richardson D, Hodsman A, van Schalkwyk D, Tomson C, Warwick G. Management of anaemia in haemodialysis and peritoneal dialysis patients (chapter 8). Nephrol Dial Transplant;22 Suppl 7:vii78-104. 2007. 
10.Suhardjono. Hemodialisis; prinsip dasar dan pemakaian kliniknya. Dalam: Setiati, S., Alwi, I.,

Sudoyo, A. W., K., M. S., Setiyohadi, B., dan Syam, A. F., penyunting. Buku Ajar Ilmu Penyakit Dalam. Edisi ke-6. Jakarta: Interna Publishing. hlm. 2192-6. 2014.

11.Suwitra, K. Penyakit ginjal kronik. Dalam Setiati, S., Alwi, I., Sudoyo, A. W., Simadibrata, M., dan Setiyohadi, B., penyunting. Buku Ajar Ilmu Penyakit Dalam. Edisi ke-2. Jakarta: Interna Publishing.hlm 570-579. 2006.

12.Syaifuddin. Anatomi Fisiologi Kurikulum Berbasis Kompetensi untuk Keperawatan \& Kebidanan.Edisi ke-4. Jakarta : EGC.hlm 446-153. 2011.

13.Ulya I. Perbedaan Kadar Hemoglobin Pra dan Post Hemodialisis Pada Penderita Gagal Ginjal Kronik di RS PKU Muhammadiyah Yogyakarta, Fakultas Kedokteran Universitas Muhammmadiyah Yogyakarta. Yogyakarta: Skripsi. 2007.

14.https://www.kidney.org/kidneydisease/aboutckd [Diakses tanggal 4 Desember 2015]

15.https://www.scribd.com/doc/66144739/Derajat-Anemia-Dan-Penatalaksanaannya 